\title{
The Use of Questioning Strategy to Improve Students' Reading Comprehension
}

\author{
Ana Rizqi Amalia \& Yeni Mardiyana Devanti \\ Universitas Muhammadiyah Jember \\ (yenidevanti@gmail.com)
}

\begin{abstract}
This research is a classroom action research which was conducted at SMA Muhammadiyah Jember. It is aimed at improving students' reading comprehension by the use of questioning technique. The second grade students were taken as the subjects of the research. They are all thirty-two students. The data were collected from in-depth-interview during the process of teaching and learning and test which was given in the end of the process. In the first cycle, there were twenty students (62.5\%) who gain the criteria of success. Meanwhile, in the second cycle, twenty-six students (81.25\%) gain the target score. This showed that the students were successful in reading comprehension class. The conclusion of the study is that the use of Questioning Strategy can improve the second grade students' reading comprehension of SMA Muhammadiyah 2 Jember.
\end{abstract}

Keywords: reading comprehension, questioning strategy.

Reading is the act of interpreting printed or written words and requires understanding or comprehension of the meaning of the reading text. Through reading we can get the messages that the writer has expressed. Harmer (1998, p. 68) states, "there are many reasons why getting students to read English texts is an important part of the teacher's job. In the first place many students want to be able to read text in English either for their careers, for study purpose or simply for pleasure".

Tenkersley (2003, p. 90) states that good readers have a purpose for reading and use their experiences and background knowledge to make sense of the text. Making connections is the key to comprehension. Comprehension means making sense of words, connecting ideas between texts and prior knowledge, constructing and negotiating meaning in discussions with others. Comprehending the texts refers to understanding their context, not only comprehending words, but also paragraphs and text. Readers read the text to get opinions or ideas that are related to the text and to understand what it tells about. It means reading is a process to understand the content of and to get information from the reading text.

In fact, there are often some phenomena in many schools, in which many students find difficulties in comprehending the text. The second grade students' of SMA Muhammadiyah Jember, had a difficulty in comprehending a text occurred might be caused by inappropriate strategies and activities conducted in the teaching of reading comprehension. The teachers only gave the texts and exercise in the book without giving any explanations about the text and how to answer the question. Then, the students read and answer the question which is given by the teacher. Most of students did not understand 
the content and the message of the text they just find the same literature based on the text.

Based on the condition above, the researcher wants to increase students' reading comprehension by using Question Strategy. According to Tankersley (2003, p. 93), "questioning while reading is a key to developing good comprehension. Proficient readers question the content, the author, the events presented, the arguments, and the issues and ideas in the text. Students need to be taught how to ask questions during reading to monitor comprehension as well as to process the information that they are receiving".

It is necessary to develop meaningful and effective questioning strategies. Questions have the ability to direct and focus a student's reading comprehension and serve a source of ideas. Therefore, in order to tap a variety of mental operations, many different levels and types of questions should be developed. According to Flood (1984, p. 255), "While questioning stimulates and directs thinking, it is also necessary to supplement your instruction with work conception formations or schema development". This means developing students' knowledge, background, experience so that they will have a large pool of knowledge from which to draw when they are reading. Through instruction with work in conception formation or schema development, you may positively affect a child comprehension.

Questioning is among the social competencies that children bring with them to their schooling. But when they enter school, many children begin to think of questions in terms of answering the teacher's questions rather than asking and answering their own (Moreillon, 2007). Maker and Nielson (in Shaunessy, 2005 , p. 6) noted, "advised teachers of the gifted to incorporate questioning strategies so that students will learn how to explain, elaborate, or clarify their often abstract ideas". According to Smith (1980, p. 228), Questions are, of course, the mainstays of teachers as they attempt to measure comprehension and they are usually vital parts of reading purposes. It is wisely used by pupil and teacher to enhance understanding. Although a continuing goal of the teacher should be able to help pupils learn to set their own purposes by creating their own question, this cannot be done all at once or overnight.

Procedure of Questioning Strategy is as follows.

\section{Pre-reading activities}

Pre-reading activities is the first activities in questioning strategy is preparing students to read, making sure that they get off to a good start. In pre-reading has several purposes; first, they motivate students interest and build background knowledge on the topic of the text the students are so read. Students may have little or no knowledge of the text topic, or they may have misconceptions about the topic that can be clarified during the prereading phase. Second, during the pre-reading phase, students clarify their purpose for reading a particular text. The third is to help students gain a general idea of the text's organization and content by perusing the headings, subheadings, table of contents and so forth.

\section{During-reading activities}

During-reading activities help the students monitor the comprehension based on the purpose they have set for reading (Leal, Crays, \& Moetz, 1985). They need to ask themselves, "Did I find what I was looking for?" if they have a clearly set purpose, they will be able to determine their success while reading. In addition, the students can use the structure of their texts to assist them with finding information based on their purpose. When students know what they are looking for and what they will be doing with the information later, they will be better able to evaluate their own reading. This metacognitive aspect is the key of comprehension. If the English learners have not established a purpose for their reading, they will not be able to evaluate whether they have been successful readers. When they check their understanding based on the purpose they have set, then they 
are monitoring their comprehension. So the purpose established for reading a chapter in your classroom will determine how the students will monitor their comprehension during reading.

\section{Post-reading activities}

Post-reading activities are the last activities in Questioning strategy, they can guide students in noting and coding specifics about the questions. If students have developed background knowledge for a text, set a purpose for reading, and monitored their comprehension during reading, next they must organize the information.

The question that is attempted to answer in this study is that 'does the students' reading comprehension increase since they are taught by the use of questioning technique?'

\section{Method}

Classroom action research is chosen to improve the quality of teaching and learning process in the classroom. In this research, the researchers identify the problem, apply the strategy, observe some practices, and conduct reflecting. According to Kemmis and McTaggart (2000) action study is a participatory study consisting of spiral of following self-reflective cycles:

The data are taken during observing process by interview. Then it is analyzed by triangulating with the test result.

\section{Result and Discussion}

\section{The Description of Action in Cycle I}

This research was conducted in the second grade students of XI IPS class at SMA Muhammadiyah 2 Jember. In cycle I, the first step in doing action research was planning the action. The researcher decided when the action could be started, and what was the best way to implement reading comprehension using Questioning Strategy to the second

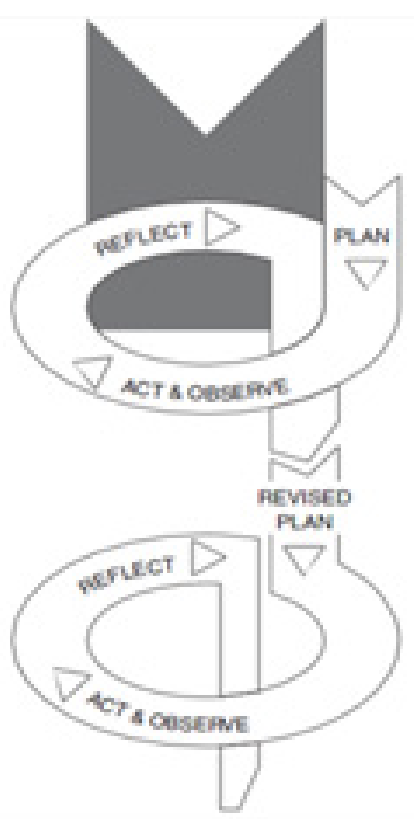

Picture 1. Kemmis and McTaggart's (2000) Action Research Spiral

grade students of XI IPS class. The researchers also decided about the material that would be given to the students. Here the researcher used Hortatory Exposition Text as the material, then provided the Hortatory Exposition Text with some questions dealing with the reading comprehension exercises. After that the researcher prepared two lesson plans for the teaching learning process in cycle I based on the curriculum of KTSP (2006), the first lesson plans for meeting 1 and the second lesson plans for meeting 2 .

The implementation in meeting 1 was based on the first lesson plan and the time allocation was 90 minutes. Here the researcher conducted Questioning Strategy in the teaching learning process of reading comprehension. The researcher asked some general leading questions about the topic of text that would be taught, then built students' background knowledge about Hortatory Exposition Text and related it to the students' life. After that the researcher explained the definition, the generic structure and the language features of Hortatory Exposition Text. After giving explanation the researcher distributed an 
example of hortatory exposition text to the students, read aloud sentence by sentence to the students with correct pronunciation, then the students followed what the researcher had read until finished. After that the researcher pointed some students to read the hortatory exposition text in turns. While the students were reading the text, the researcher corrected their pronunciation. Afterward the researcher guided the students in comprehending the content of the text, finding all of information of the text and discussing some difficult words. Furthermore, the researcher grouped the students, there were 32 students and each group consisted of four students, so there were eight groups. Each group got a hortatory exposition text with the same topic provided with some questions dealing with the content of the text. They should comprehend all the information of the text and answer the questions based on the text.

The implementation in meeting 2 was based on the second lesson plan that had been made by the researcher, and the time allocation was 90 minutes. Here the researcher directly gave a hortatory exposition text to the students with different topic from the previous meeting. Afterward the researcher continued the teaching reading comprehension based on the procedure of Questioning Strategy. Then, the researcher grouped the students. The members of the group were different from the previous meeting, the researcher also provided a different topic of hortatory exposition text with the previous meeting to avoid the students' boredom.

Observing was done after the second meeting of cycle I. In this research the researcher used a systematical observation. It focused on the result of teaching learning process of reading comprehension Questioning Strategy by using a reading test and observation as the instrument of observation. The researcher used multiple choice test item which consisted of 40 items, each item had four options namely A, B, C and D. Dealing with the scoring, each correct answer was scored 2.5 point and zero for each wrong answer, so the total score of the test is 100 if all of the questions could be answered correctly.

Reflecting was done after calculating the students' score of reading test. The percentage of students who scored $\geq 70$ was $59.37 \%$. Based on the reading test result of cycle I, it could be known that the standard requirement of the percentage scores of the students in reading comprehension was $75 \%$ of the students got $\geq$ 70 had not been achieved yet. It was because the students were still unfamiliar with this new strategy in the teaching learning process. Furthermore, the students did not have enough background knowledge, so it was difficult for them.

The action in cycle II needed some revisions, such as making the students more familiar with the strategy, gave an interesting topic provided with some pictures related to the text to make students more interested and understand the material better during the teaching and learning process.

\section{The Description of Action in Cycle II}

Since the result of the actions in cycle I had not achieved the objective of the research yet, the researcher implemented cycle II.

Like the first step in cycle I the researcher decided the suitable material that would be given to the second grade students of XI IPS class. The material was still hortatory exposition text, but based on the reflecting in cycle I, it needed some changes to revise planning and the implementation of the action that were done. So in this cycle II the researcher prepared the different topic of hortatory exposition text that was more interesting than in cycle I. Here the researchers not only provided the hortatory exposition text with some questions related to the text, but also provided some pictures related to the text. Those all were expected to assist the students in comprehending the hortatory exposition text, so that they would be more motivated to improve their reading comprehension and could reach the target score. The researchers 
also designed two lesson plans in cycle II based on the curriculum of KTSP (2006), the first lesson plans for meeting 1 , and the second lesson plan for meeting 2 .

The implementation of the action in cycle II was based on planning and implementation revised in the cycle I. Here the researchers conducted the teaching learning process of reading comprehension still based on the procedure of Questioning Strategy, but in this cycle II the researcher provided different topic of hortatory exposition text that was more interesting for the students. The researcher also supported it by providing some pictures related to the text, each topic had one picture. Those all were expected to make the students understand the material and could improve their reading comprehension.

The implementation in meeting 2 was based on the second lesson plan that had already been prepared by the researcher, and the time allocation was 90 minutes. In this second meeting of cycle II the researchers continued the teaching learning process of the test in cycle I.

The reflection was done after calculating the test score of cycle II. Based on the calculation, the percentage of students who scored $\geq 70$ was $80 \%$. It means that the minimum standard score requirement of the students in reading comprehension had already been achieved. The action can be stopped in cycle II.

In conclusion, Questioning Strategy is able to improve students' reading comprehension of hortatory exposition text by giving some activities that can make the students active and work at much higher level than is possible on their own.

The reading test in cycle I was conducted on Thursday May 24th 2016 to know how far the students can improve their reading comprehension after the implementation of the action using Questioning Strategy. The test was administered after the second implementation of cycle I and it was followed by 32 students. In this research the target score of the students was $\geq 70$ and it must be achieved by $75 \%$ of the students.

Table 1. The Result of Reading Comprehension Test in Cycle I

\begin{tabular}{cc}
\hline The Data Results & Percentage (\%) \\
\hline The students who got score $\geq 70$ & $62.5 \%$ \\
\hline The students who got score $<70$ & $37.5 \%$ \\
\hline
\end{tabular}

reading comprehension based on the procedure of Questioning Strategy. Unlike the action in cycle I, here the class was more conducive as the students had practiced more and they became more familiar with the Questioning Strategy.

The observing was focused on the result of teaching learning process of reading comprehension through Questioning Strategy by using a test and checklist. The researcher still used multiple choice test item which consisted of 40 items. Each item had four options namely $\mathrm{A}, \mathrm{B}, \mathrm{C}$ and $\mathrm{D}$ just like in cycle I, but in this cycle II the researchers mixed up the item number of the test to make a difference with
Based on the result of reading test in Table 4.1 above, it was found that the percentage of students who got score $\geq 70$ was $62,5 \%$ and the percentage of students who got score $<70$ was $37,5 \%$. It means there were 20 of 32 students who got score $\geq 70$, and there were 12 of 32 students who got score $<70$ in cycle I.

There was improvement from $28 \%$ in the preliminary study up to $62 \%$ in cycle I, but the result of reading comprehension test could not reach the criteria of success that was $75 \%$. As mentioned before, the cycle of this research was considered to be successful if $75 \%$ students got score $\geq 70$. It means that the action in cycle 
I was not successful yet and it was necessary to continue the action to cycle II.

Based on the observation checklist in cycle $\mathrm{I}$, in the first meeting there were 13 of 32 students (40.62\%) who active in the class and there were 19 of 32 students (59.37\%) who passive in the class. Meanwhile in the second meeting there were 18 of 32 students (56.25\%) who active in the class and there were 14 of 32 students $(43.75 \%)$ who passive in the class. The average result of the observation checklist in cycle I were $48.43 \%$ student active in the class and $51.56 \%$ student passive in the class.

The reading test in cycle II was conducted on Thursday, May 31st 2016. The test was administered after the second implementation of cycle II and it was followed by 32 students.
Based on the observation checklist in cycle II, in the first meeting there were 23 of 32 students $(71.81 \%)$ who active in the class and there were 9 of 32 students (28.12\%) who passive in the class. Meanwhile in the second meeting there were 26 of 32 students $(81,25 \%)$ who active in the class and there were 6 of 32 students (18.75\%) who passive in the class. The average result of the observation checklist in cycle II were $76.56 \%$ student active in the class and $23.43 \%$ student passive in the class.

The result of the reading test indicated that using questioning strategy could increase the students' reading comprehension. By using questioning strategy made the students easier to study English especially in reading subject. They were able to comprehend the meaning of the word comprehension, sentence

Table 2. The Result of Reading Comprehension Test in Cycle II

\begin{tabular}{cc}
\hline The Data Results & Percentage (\%) \\
\hline The students who got score $\geq 70$ & $81,25 \%$ \\
\hline The students who got score $<70$ & $18,75 \%$ \\
\hline
\end{tabular}

Based on the result of reading test in Table 4.2 above, it was found that the percentage of students who got score $\geq 70$ was $81.25 \%$ and the percentage of students who got score $<70$ was $18.75 \%$. It means that there were 26 of 32 students who got score $\geq 70$, and there were 6 of 32 students who got score $<70$ in cycle II (See Appendix 18). So, the target percentage of the research that was $75 \%$ of the students got $\geq 70$ has been achieved.

There was improvement from $62.5 \%$ in cycle I up to $81.25 \%$ in cycle II. This research was successful and the teaching reading comprehension through Questioning Strategy could reach the criteria of success. So, the action was stopped, and it is unnecessary to continue the action into the next cycle because more than $75 \%$ of the students could achieve the target score. comprehension, paragraph comprehension and text comprehension.

\section{Conclusion}

Based on the results of the reading test and the discussions in the previous chapter, the conclusion of this research is, Questioning Strategy could improve the second grade students' reading comprehension and students participation at SMA Muhammadiyah 2 Jember, Indonesia.

\section{References}

Flood, James / Salus, Peter H. 1984. Language and The Language Arts. Englewood Cliffs: Prentice-Hall, Inc. 
Harmer, J. 1998. How to Teach English. England: Longman.

Linse, Caroline and David Nunan. 2005. Practical English Language Teaching: Young Learners. McGraw-Hill: New York.

Moreillon, Jeremy. 2007. Collaborative Strategies for Teaching Reading Comprehension. USA: American Library Association.

Shaunnessy, Elizabeth. 2005. Questioning Strategies for Teaching the Gifted. Prufrock Press.

Smith, B Nila. 1980. Reading Instruction for Today Children (2nd edition). Englewood Cliffs: Prentice-Hall, Inc.

Tankersley, K. 2003. The Threads of Reading Strategies for Literacy Development. USA: ASCD. 
